\title{
Modulation of active-break spell of Indian summer monsoon by Madden Julian Oscillation
}

\author{
Madhu Singh and R Bhatla* \\ Department of Geophysics, Institute of Science, Banaras Hindu University, Varanasi 221 005, India. \\ *Corresponding author.e-mail: rbhatla@bhu.ac.in
}

MS received 16 August 2017; revised 27 April 2018; accepted 27 June 2018; published online 13 March 2019

The Madden Julian Oscillation (MJO) is the major fluctuation in tropical weather on weekly to monthly time scale and a major driver of Indian summer monsoon (ISM). In this study, using Indian Meteorological Department (IMD) high resolution daily gridded rainfall data and Wheeler-Hendon MJO indices, the daily rainfall distribution over India associated with various phases of eastward propagating MJO was examined to understand the MJO-monsoon rainfall relationship. The present study reveal that the onset of break and active events over India and the duration of these events are strongly related to the phase and strength of the MJO. The break events were relatively better associated with the strong MJO phases than the active events. About $80 \%$ of the break events were found to be set in during the phases 1, 2, 7 and 8 of MJO with maximum during phase 1 (34\%). On the other hand, about $58 \%$ of the active events were set in during the MJO phases 3-6 with maximum during phase $6(21 \%)$. The results of this study indicate an opportunity for using the real time information and skillful prediction of MJO phases for the extended range prediction of break and active conditions.

Keywords. Active-break spell; intraseasonal variability; MJO; modulated rainfall.

\section{Introduction}

The large scale rainfall over India during southwest monsoon season (June-September) is received in spells (active period) with intermediate dry spells (break period). The active spell (break spell) is characterized by precipitation maxima (minima) over the core monsoon zone (Gadgil and Joseph 2003; Rajeevan et al. 2010). These spells are thought to be associated with shift in the location of the monsoon trough (Krishnamurthy and Ardanuy 1980; Bhatla et al. 2004; Ding and Sikka 2006). Krishnamurti et al. (1985) have shown that the planetary-scale MJOs couple with a northward-propagating divergence wave, thereby modulating the Indian monsoon active (break) spells. Annamalai and Slingo (2001) reveal that the strength of large scale Hadley and east-west circulations increases (decreases) significantly during active (break) phase. Chen et al. (1988) suggested that the MJO couple with and steers northward low-level, 30-50 day monsoon troughs and ridges that originate near the equator through a transient Hadley circulation (Yasunari 1981); this steering in turn induces active (break) of the Indian summer monsoon. Lau and Chan (1986) argue that northward propagation results from interaction between MJOs and monsoon circulation. Bhatla et al. (2015) have shown that the convection anomalies along monsoon trough region are responsible 
for interannual variability of rainfall over Gangetic plains. Bhatla et al. (2016) illustrates that the outgoing long wave radiation (OLR) anomaly is negative(positive) during pre(post) onset years. The strength of MJO modulated precipitation is comparable to the interannual variability (Barlow et al. 2005). There is El-Nino type situation when 30-60 days mode dominates due to moisture transport to the Pacific with comparatively dry conditions over Indian landmass (Kulkarni et al. 2011).

Several studies have shown that northward propagating intraseasonal oscillations (NPISOs) are linked to MJOs (Yasunari 1979, 1980; Lau and Chan 1986; Rui and Wang 1990; Gadgil and Asha 1992; Krishnamurthy and Shukla 2008). Zhang (2005) provides review on MJO teleconnections. Joseph et al. (2009) reveal that the divergent Rossby wave associated with the dry phase of equatorial convection propagate westward towards Indian land, coupled with the northward propagating dry phase and leads to prolonged breaks. Valadao et al. (2016) have shown increased precipitation during MJO phases 1-2 and suppressed precipitation during MJO phases 5-6 over northeast Brazil. Zheng et al. (2016) have suggested that the regional rainfall dominates the strong (weak) rainfall periods compared to monthly rainfall. The stronger rainfall over northwest, central and peninsular India during strong monsoon is generally caused by prolonged wet spells followed by short and weak dry spells and vice versa (Zheng et al. 2016). Abhilash et al. (2014) have studied extended range prediction of active-break spells of Indian summer monsoon rainfall using an ensemble prediction system (EPS). The present study may be useful for the extended range prediction of monsoon rainfall. The main objective of this study was to use the rainfall criteria of Pai et al. (2016) to identify the break and active spells for 114 years (1901-2014) and list them. Another objective was to examine short spell, intermediate spell and long spell active (break) cycle corresponding to different MJO phases. The short and long break spell are validated using the results of Joseph et al. (2009). Emphasis was also given to examine the association between the break/active spells with that of MJO phase and amplitude variations to find dynamics of prolonged break/active spells. The study further examined the differences between the composite rainfall patterns of the break and active spells. This study examines the MJO modulated rainfall associated with the break and active spells. Section 2 describes the data and methodology used in this study. Section 3 discusses various results of the study and finally section 4 presents summary and conclusions of this study.

\section{Data and methodology}

To examine the association of the break and active events with the various phases of MJO, the break and active events for the period 1979-2014 were considered from the list of these events provided for the period 1901-2014 in Pai et al. (2016). Furthermore, the break spell have been divided into three different categories depending upon their duration: (1) short breaks, duration: 3 days; (2) intermediate breaks, duration: $4-7$ days and (3) long-breaks, duration: 8 days or more. Similarly, active spell has been divided into three different categories depending upon their duration: (1) short spell active event, duration: 3 days; (2) intermediate spell active event, duration: $4-7$ days and (3) long spell active event, duration: 8 days or more.

The dataset used in the study for examining MJO modulated rainfall corresponding to different MJO phases was the IMD high resolution $\left(0.25 \times 0.25^{\circ}\right)$ gridded daily rainfall dataset over India for the period 1979-2013. The real-time multivariate MJO indices (RMM1 and RMM2) of Wheeler and Hendon (2004) were used for defining the various phases of MJO. The data were obtained from http://www.bom.gov.au/climate/ mjo/graphics/rmm.74toRealtime.txt. Wheeler and Hendon (2004) have suggested that RMM1 and RMM2 are mathematical methods that combine cloud amount and winds at upper and lower levels of the atmosphere to provide a measure of the strength and location of the MJO. The MJO indices were calculated as the principal component (PC) time series of the two leading empirical orthogonal functions (EOFs) of combined daily mean fields of 850 and $200 \mathrm{hPa}$ zonal winds and OLR averaged over the tropics $\left(15^{\circ} \mathrm{S}-15^{\circ} \mathrm{N}\right)$. These indices are useful in viewing the MJO in a way that is reminiscent of the original schematic of Madden and Julian (1972). It comprises convectively-coupled, vertically oriented circulation cells that propagate eastward around the globe along the equator and recurs every 30 to 60 days. The high resolution $\left(0.25 \times 0.25^{\circ}\right)$ GPCP (Global Precipitation and Climatology Project) precipitation data and OLR data obtained from the website http://www.esrl.noaa.gov/psd/ is used for the study of extreme active and extreme break events. 
Table 1. The strong (weak) MJO days and cycle corresponding to different MJO phases during active-break spells for the period 1979-2014.

\begin{tabular}{|c|c|c|c|c|c|c|c|c|c|c|}
\hline \multicolumn{5}{|c|}{ Active spell } & \multicolumn{4}{|c|}{ Break spell } & \multirow{2}{*}{$\begin{array}{c}\text { Strong (weak) } \\
\text { days }\end{array}$} & \multirow{2}{*}{$\begin{array}{l}\text { AB-Cycle } \\
\text { (year) }\end{array}$} \\
\hline Phase & Amplitude & Strong & Weak & Year & Amplitude & Strong & Weak & Year & & \\
\hline $\mathrm{P}-1$ & 1.80 & 16 & 11 & 11 & 2.89 & 67 & 31 & 21 & $83(42)$ & 32 \\
\hline P-2 & 1.57 & 14 & 13 & 11 & 2.32 & 38 & 15 & 15 & $52(28)$ & 26 \\
\hline P-3 & 1.56 & 8 & 14 & 8 & 1.95 & 13 & 8 & 8 & $21(22)$ & 16 \\
\hline $\mathrm{P}-4$ & 2.25 & 12 & 22 & 13 & 1.01 & 4 & 3 & 3 & $16(25)$ & 16 \\
\hline P-5 & 2.37 & 24 & 16 & 13 & 0.95 & 7 & 0 & 4 & $31(16)$ & 17 \\
\hline P-6 & 2.22 & 39 & 15 & 13 & 2.35 & 17 & 7 & 7 & $56(22)$ & 20 \\
\hline P-7 & 1.72 & 13 & 13 & 11 & 2.54 & 25 & 20 & 10 & $38(33)$ & 21 \\
\hline P-8 & 1.63 & 15 & 12 & 11 & 2.31 & 10 & 29 & 10 & $25(41)$ & 21 \\
\hline
\end{tabular}

\section{Results and discussion}

The day-to-day variations of MJO phase and amplitude are analyzed for break and active spells during 1979-2014. The strong(weak) MJO events corresponding to different phases of MJO for active(break) events during 1979-2014 are listed in table 1 . The result suggests 289 break events and 257 active events during 36 years of study period, associated with MJO phase and amplitude variations in Indian Ocean and western Pacific. It is found that $63 \%$ strong breaks and $37 \%$ weak breaks occur out of 289 break days. However, $55 \%$ strong active events and $45 \%$ weak active events occur out of 257 active days, it indicates that the strong active(break) events are more compared to weak active(break) events. Whereas, analysis also shows that the active events are less as compared to break events.

\subsection{MJO amplitude-phase variations during break spells}

The monsoon breaks predominantly occur during MJO phases 1 ( $29 \%$ of days), 2 ( $18 \%$ of days), 6 ( $19 \%$ of days) and 7 ( $13 \%$ of days) out of 289 breaks identified during the period 1979-2014 (table 1). The monsoon breaks are least (2\% of days) during MJO phases $4-5$. The maximum strong breaks (66\% of days) occur during MJO phase 1 out of 125 break events and minimum strong breaks $(38 \%$ of days) occur during MJO phase 8 out of 66 break events. Thus, the strong breaks occur during phases 2 ( $72 \%$ of days), 1 (68\% of days), 7 (56\% of days) and 8 (29\% of days). The strong MJO phase 8 breaks are less as compared to weak breaks. The maximum MJO break cycle occurs during phases 1 ( $57 \%$ of years) and 2 (41\% of years) and minimum
MJO break cycle occurs during MJO phase 4 (8\% of years).

The short, intermediate and long spell breaks are listed in table 2 corresponding to different MJO phases. The short spell breaks mostly occur during phases 2, 7, 8 and 1 . The strong short spell breaks mostly occur during phases 2 and 7 . However, the weak short spell breaks mostly occur during MJO phases 8 and 7 . The short spell break cycle mostly occur during MJO phase 2 (41\% of years) followed by MJO phases 8 (27\% of years) and 7 (24\% of years). The intermediate breaks mostly occur during phases 1, 2 and 8 . The strong intermediate breaks are maximum during phases 1 and 2. However, the weak intermediate breaks are maximum during phase 1 . The intermediate break spell cycle is highest during phases 1 (35\% of years) and 8 (16\% of years). There occur no long breaks during phase 4 (table 2). The long breaks mostly occur during strong MJO phases. The result suggests that the long breaks occur mostly during MJO phases 7 and 1. The long spell breaks are less frequent as compared to the short spell and intermediate spell breaks. It leads to the conclusion that most of the breaks are intermediate spell breaks. The MJO amplitude variation of short spell breaks is maximum (table 3) during MJO phases 6-7. The intermediate and long spell show highest MJO amplitude during phase 1 . Thus, the MJO amplitude variation is seen during initial (phases 1-3) and terminating phases (7-8). However, the MJO amplitude variation during intermediate phases $4-6$ is least (tending to zero).

\subsection{MJO amplitude-phase variations during active spells}

The active spell is most frequent during intermediate MJO phases 4-6 (table 1). The active spell of 
Table 2. The frequency of MJO phases corresponding to short, intermediate and long active/break spells.

\begin{tabular}{|c|c|c|c|c|c|c|c|c|c|c|c|c|c|c|c|c|c|c|}
\hline \multicolumn{10}{|c|}{ Active spell } & \multicolumn{9}{|c|}{ Break spell } \\
\hline \multirow[b]{2}{*}{ Phase } & \multicolumn{3}{|c|}{ Short } & \multicolumn{3}{|c|}{ Intermediate } & \multicolumn{3}{|c|}{ Long } & \multicolumn{3}{|c|}{ Short } & \multicolumn{3}{|c|}{ Intermediate } & \multicolumn{3}{|c|}{ Long } \\
\hline & $\mathrm{S}$ & $\mathrm{W}$ & $\mathrm{Y}$ & $\mathrm{S}$ & $\mathrm{W}$ & $\mathrm{Y}$ & $\overline{\mathrm{S}}$ & $\mathrm{W}$ & $\overline{\mathrm{Y}}$ & $\mathrm{S}$ & $\mathrm{W}$ & $\mathrm{Y}$ & $\mathrm{S}$ & $\mathrm{W}$ & $\mathrm{Y}$ & $\mathrm{S}$ & $\mathrm{W}$ & $\bar{Y}$ \\
\hline $\mathrm{P}-1$ & 14 & 7 & 10 & 0 & 3 & 1 & 3 & 2 & 1 & 8 & 8 & 7 & 41 & 15 & 13 & 18 & 8 & 6 \\
\hline $\mathrm{P}-2$ & 10 & 7 & 8 & 0 & 6 & 2 & 6 & 0 & 2 & 38 & 15 & 15 & 25 & 0 & 5 & 9 & 2 & 5 \\
\hline P-3 & 11 & 4 & 7 & 2 & 4 & 2 & 2 & 2 & 2 & 13 & 8 & 8 & 10 & 4 & 5 & 0 & 1 & 1 \\
\hline P-4 & 14 & 4 & 8 & 7 & 6 & 3 & 6 & 2 & 2 & 4 & 3 & 3 & 4 & 3 & 3 & 0 & 0 & 0 \\
\hline P-5 & 4 & 3 & 5 & 10 & 14 & 7 & 3 & 1 & 2 & 0 & 7 & 4 & 0 & 5 & 2 & 0 & 1 & 1 \\
\hline P-6 & 4 & 9 & 4 & 10 & 21 & 10 & 9 & 2 & 3 & 8 & 16 & 7 & 8 & 2 & 2 & 3 & 9 & 3 \\
\hline P-7 & 2 & 5 & 3 & 11 & 6 & 8 & 2 & 0 & 1 & 22 & 20 & 9 & 6 & 5 & 3 & 16 & 14 & 6 \\
\hline P-8 & 7 & 6 & 6 & 6 & 9 & 5 & - & - & - & 10 & 24 & 10 & 3 & 13 & 6 & 3 & 13 & 6 \\
\hline
\end{tabular}

S: Strong, W: Weak, Y: Year.

Table 3. The MJO amplitude variations during short, intermediate and long active/break spells for different MJO phases.

\begin{tabular}{lccccccc}
\hline & \multicolumn{3}{c}{ Active spell } & & \multicolumn{3}{c}{ Break spell } \\
\cline { 2 - 3 } Phase & Short & Intermediate & Long & & Short & Intermediate & Long \\
\hline P-1 & 1.66 & 0.3 & 0.3 & & 1.07 & 2.30 & 2.89 \\
P-2 & 1.57 & 0.27 & 0.27 & & 2.32 & 1.54 & 0.65 \\
P-3 & 1.69 & 1.21 & 0.03 & & 1.95 & 1.95 & 0 \\
P-4 & 2.02 & 2.09 & 1.21 & & 1.02 & 1.02 & 0 \\
P-5 & 2.37 & 2.14 & 0.64 & & 0.95 & 0.95 & 0 \\
P-6 & 1.99 & 2.16 & 0.44 & 2.35 & 0.50 & 2.35 \\
P-7 & 1.55 & 1.72 & 0.05 & 2.53 & 0.64 & 2.35 \\
P-8 & 1.63 & 1.21 & - & 2.31 & 1.18 & 1.18 \\
\hline
\end{tabular}

monsoon is modulated by phase 6 ( $21 \%$ of days), 5 ( $16 \%$ of days) and 4 (13\% of days) during total 257 active spells. The phase 3 was the least active phase (only $9 \%$ of days). The strong (weak) active events show increasing (decreasing) order from phase 4 to 6 . The maximum ( $72 \%$ of days) strong active events occur during phase 6 out of total phase 6 events identified and minimum (35\% of days) strong active events occur during phase 4 out of total phase 4 events identified. Thus, the strong active events occur during phase 4 (35\% of days), 5 ( $60 \%$ of days) and 6 ( $72 \%$ of days). The strong phase 4 events are less as compared to weak events. The maximum active cycle occurs during phases 4-6 (35\% of years) and minimum active cycle occurs during phase 3 ( $22 \%$ of years).

The short, intermediate and long spell active events corresponding to different MJO phases are listed in table 2. The short spell active events mostly occur during phases 1, 2 and 4. The strong short spell active events preferably occur during phases 1 and 4. However, the weak short spell active events preferably occur during phases 6 and
8. The short spell active cycle mostly occur during phases 1 ( $27 \%$ of years), 2 ( $22 \%$ of years) and 4 ( $22 \%$ of years). The intermediate spell active events mostly occur during MJO phases 5, 6 and 7. The strong intermediate spell active events are maximum during phase 7 and the weak intermediate spell active events are maximum during phases 5 and 6 . The intermediate active spell cycle is highest during phases 6 (27\% of years), 7 (22\% of years) and 5 (19\% of years). There occurs no long spell active events during MJO phase 8 (table 2 ). The long spell active events prefer weak MJO phases. The result suggests that the long spell active events occur mostly during MJO phases 6, 4 and 2. The long spell active events are less frequent as compared to the short spell and intermediate spell active events. This means most of the active spells are short spells. The MJO amplitude variation (table 3) of short spell active events is maximum during phases $4-5$ and intermediate spell active events amplitude is highest during phases $5-6$. The long spell active events show highest amplitude during phase 4 . 
(a)

Break spell

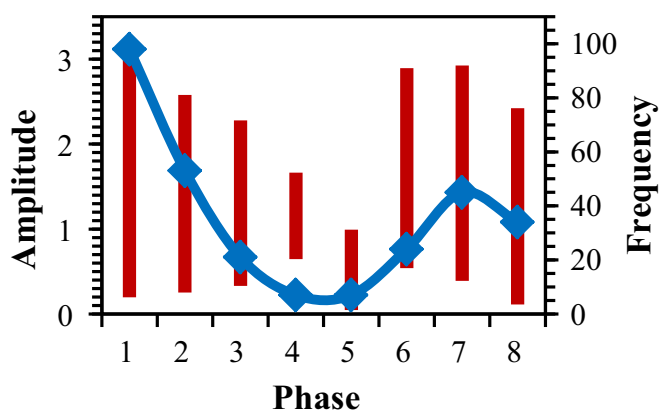

(b)

Active spell

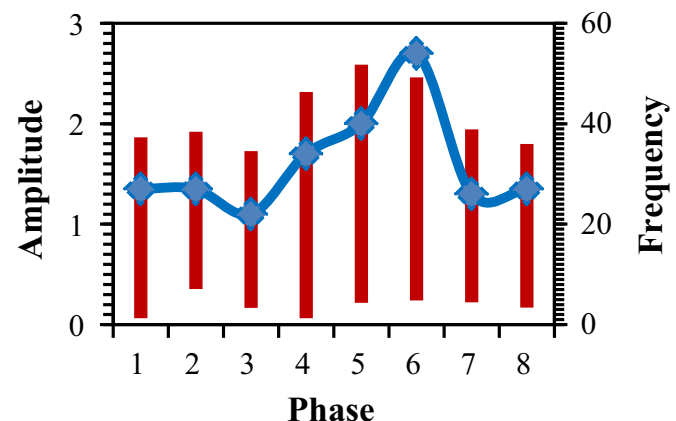

Figure 1. The MJO amplitude variations (red color bars) corresponding to different frequency (blue line) of MJO phases for (a) break spell and (b) active spell.

\subsection{MJO modulated active/break spells}

The MJO phase variations corresponding to amplitude variation (maximum-minimum) for the period 1979-2014 are depicted in figure 1( $\mathrm{a}$ and b). The MJO phase and amplitude variations during break spells are shown in figure 1(a). It is found that amplitude variations and their frequency are highest during phases 1, 2, 7 and 8 . Thus, the initial (1-2) and terminating (7-8) phases occur during break spell. The MJO amplitude variation is most frequent during phase 1 and least frequent during phase 5 . The MJO phase and amplitude variation during active spell are depicted in figure 1(b). It is clear from figure 1(b) that the MJO phases 4-6 are most frequent and amplitude variation is highest during phases $4-6$.

The year-to-year variation in average MJO amplitude during break/active spell is depicted in figure $2(\mathrm{a}-\mathrm{h})$. The average MJO phase 1 amplitude variations during active-break cycle of monsoon are shown in figure 2(a). It is observed that average phase 1 amplitude is greater during break spell than that during active spell. The break spell phase 1 amplitude peaks for the year 1979 and the active spell phase 1 amplitude peaks for the year 1995 . The minimum phase 1 amplitude during break spell occur in the year 1998 and the minimum phase 1 amplitude during active spell occur in the year 1994. Thus, there are 10 years (out of 21 years) of increase of MJO phase 1 amplitude during break spell and there are 6 years (out of 11 years) of increase of MJO phase 1 amplitude during active spell. It is clear from figure 2(b) that the break spell MJO phase 2 amplitude is maximum in the year 1999 and the active spell MJO phase 2 amplitude is maximum in the year 2011. The minimum break spell phase 2 amplitude is seen in the year 1985 and the minimum active spell phase 2 amplitude is seen in the year 1985. There are 6 break spell years (out of 15 years) of increase in phase 2 amplitude and there are 5 active spell years (out of 11 years) of increase in phase 2 amplitude. The break spell phase 3 amplitude is maximum in the year 2005 and the active spell phase 3 amplitude is maximum in the year 2011 (figure 2c).

The minimum break spell phase 3 amplitude is seen in the year 2005 and the minimum active spell phase 3 amplitude is seen in the year 1993. Thus, there are 4 years (out of 8 years) associated with increase in phase 3 amplitude and there are 4 years (out of 8 years) associated with increase in active spell phase 3 amplitude. Figure 2(d) shows that the break spell phase 5 amplitude peaks in the year 1997 and the active spell MJO phase 5 amplitude peaks in the year 1990. The minimum break spell amplitude is observed in the year 1993 and the minimum active spell amplitude is observed in the year 1991. Therefore, the results show that there are 7 years (out of 13 years) associated with increase of phase 4 amplitude and only one year (out of 3 years) associated with increase of break spell phase 4 amplitude.

The break spell phase 5 peaks in the year 2014 and the active spell phase 5 peaks in the year 1979 (figure 2e). The minimum break spell phase 5 amplitude is seen in the year 2005 and the minimum active spell phase 5 amplitude is seen in the year 1994. Thus, there are 2 years (out of 4 years) associated with increase of break spell MJO phase 5 amplitude and there are 6 years (out of 13 years) associated with increase of active spell MJO phase 5 amplitude. The break spell MJO phase 6 amplitude is maximum in the year 2002 and the active spell MJO phase 6 amplitude is maximum in the year 1979 (figure 2f). It is clear from figure 2(f) that 
Active Spell

- Break Spell

(a)

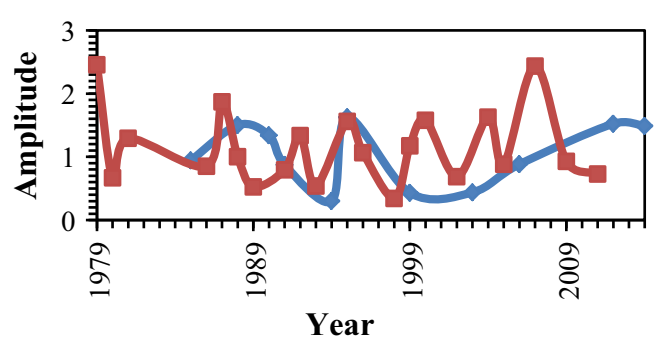

(c)

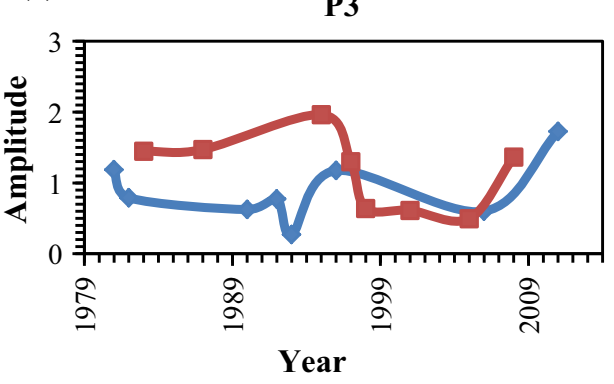

(e)

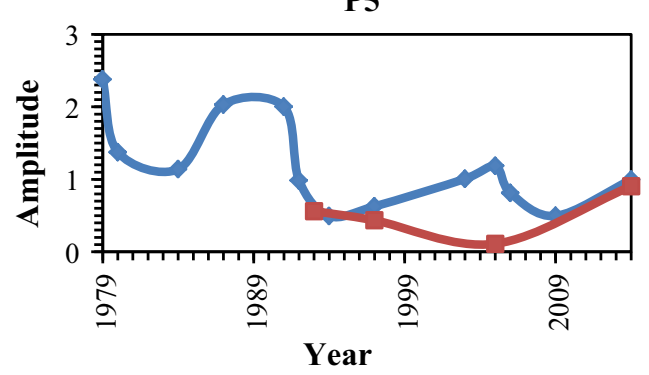

(g)

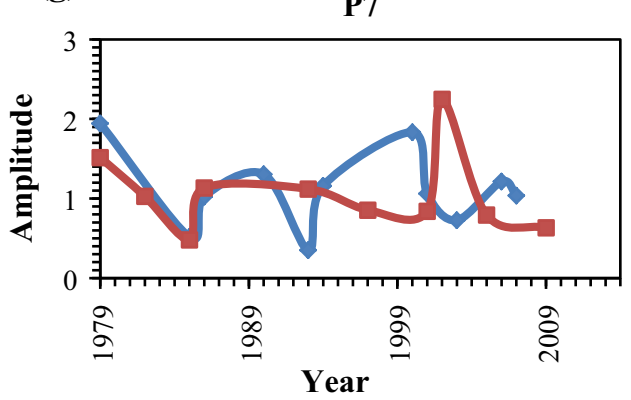

(b)

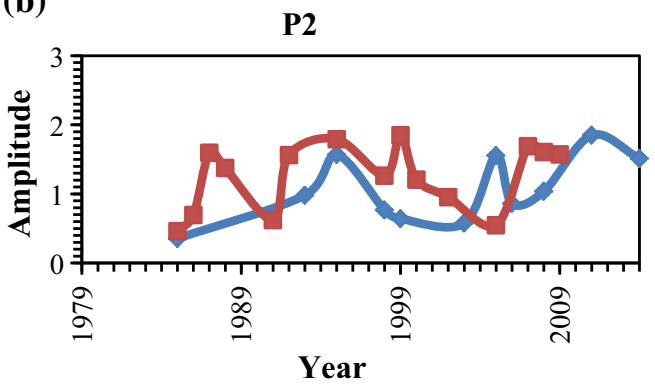

(d)

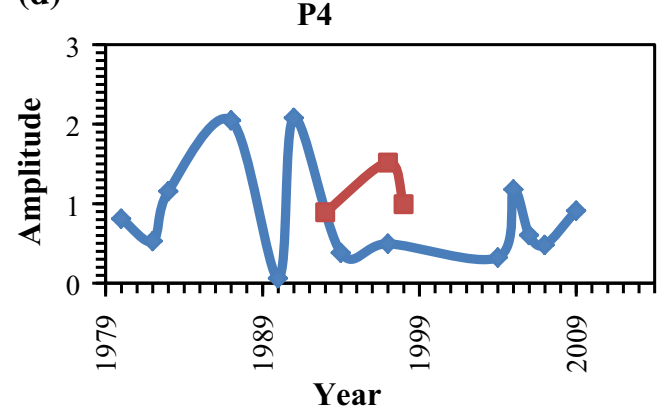

(f)

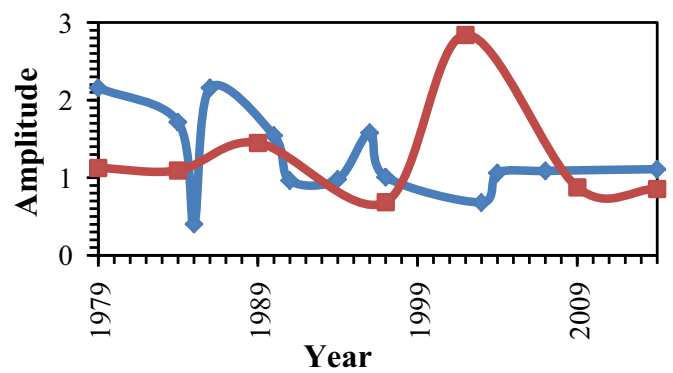

(h)

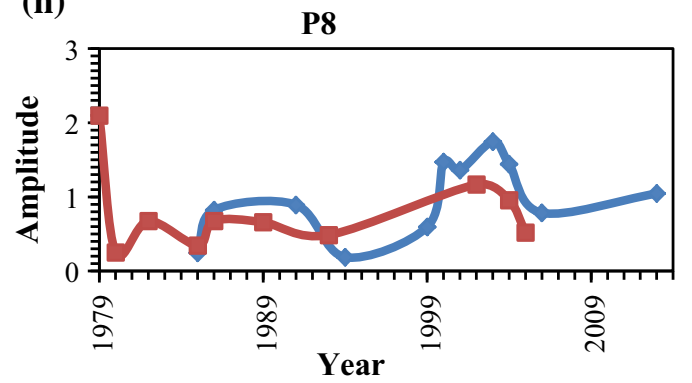

Figure 2. The year-to-year variations in average MJO amplitude for break spell (red line) and active spell (blue line) during phase 1 to phase $8(\mathbf{a}-\mathbf{h})$ for the period 1979-2014.

the break spell MJO phase 6 amplitude is minimum in the year 1997 and the active spell MJO phase 6 amplitude is minimum in the year 1985 .

The results suggest 6 break years (out of 7 years) of increase of phase 6 amplitude and 6 active years (out of 13 years) associated with increase of phase 6 amplitude. Figure 2(g) suggests that the break spell MJO phase 7 amplitude peaks in the year 2002 and the active spell MJO phase 7 amplitude peaks in the year 2000 . The minimum break spell 
MJO phase 7 amplitude is seen in the year 1985 and the minimum active spell MJO phase 7 amplitude is seen in the year 1993. Thus, there are 3 break years (out of 10 years) associated with increase in MJO phase 7 amplitude and there are 6 active years (out of 11 years) associated with increase in MJO phase 7 amplitude. The break spell MJO phase 8 amplitude is maximum in the year 1979 and the active spell MJO phase 8 amplitude is maximum in the year 2003 (figure $2 \mathrm{~h}$ ). The break spell minimum amplitude is seen in the year 1980 and the active spell minimum amplitude is seen in the year 1994. Thus, there are 5 break years (out of 10 years) associated with increase of phase 8 amplitude and there are 6 active years (out of 11 years) associated with increase of phase 8 amplitude.

\subsection{MJO-monsoon relationship}

The MJO-ISM teleconnections are addressed in terms of spatial rainfall variability over core monsoon zone. The present study deals with direct influence of the MJO on monsoon rainfall. The spatial rainfall variability over core monsoon zone during active-break spell is shown for different MJO phases (figure $3 \mathrm{a}-\mathrm{p}$ ). The composite MJO phase 1-8 rainfall anomaly during active spell and break spell shows the direct influence of MJO on monsoon rainfall.

The rainfall anomaly associated with MJO phase 1 is seen over peninsular India $(80-220 \mathrm{~mm})$, parts of northwest India $(40-80 \mathrm{~mm})$ and parts of central India (20-40 mm) (figure 3a). The MJO phase 1 is associated with break monsoon condition over major parts of central India (figure $3 \mathrm{~b}$ ). Thus, phase 1 is associated with break monsoon type condition over all India. The break monsoon condition is more pronounced during MJO phase 2 (figure $3 \mathrm{c}-\mathrm{d}$ ). The large extent of rainfall zone over Indo-Gangetic plains region (figure $3 \mathrm{~b}$ ) and smaller extent of rainfall zone over peninsular and central India (figure 3a). However, the rainfall anomaly is less during phase 2 as compared to phase 1 rainfall. The heavy rainfall events over northeast India are observed to be associated with phase 2 . The similar pattern of break monsoon condition is seen during MJO phase 3 (figure $3 \mathrm{e}-\mathrm{f}$ ). The MJO phase 3 rainfall is more over central India as compared to that during MJO phases 1 and 2. There occur pockets of heavy rainfall over peninsular India associated with MJO phase 3.

The active monsoon condition is prominent during MJO phase 4 with heavy MJO phase 4 rainfall over Western Ghats and central India (figure $3 \mathrm{~g}$ ). No rainfall condition is seen in the foothills of Himalaya (figure $3 \mathrm{~h}$ ). It is concluded that MJO phase 4 is associated with active monsoon condition over India. The MJO phase 5 rainfall shows similar rainfall distribution pattern to MJO phase 4 rainfall (figure $3 \mathrm{i}-\mathrm{j}$ ). No MJO phase 5 rainfall over foothills of Himalaya (figure $3 \mathrm{j}$ ). Thus, MJO phase 5 is associated with active monsoon condition. The MJO phase 6 rainfall condition shows active monsoon condition (figure $3 \mathrm{k}-\mathrm{l}$ ). There is little northwards shift of rainfall belt during MJO phase 7 (figure $3 \mathrm{~m}$ ) and almost no rainfall condition over central India (figure 3n). It is therefore concluded that MJO phase 7 favours the break monsoon condition. However, large amount of rainfall is seen over central India associated with MJO phase 8 (figure 3o). The MJO phase 8 rainfall over foothills of Himalaya show no rainfall condition (figure $3 \mathrm{p}$ ). The MJO phase 8 shows active monsoon rainfall distribution. However, the statistical analysis of phase 8 frequency and amplitude variation gives different result. Thus, there is doubt whether phase 8 is associated with active or break monsoon condition.

The above results give the MJO modulated rainfall during different MJO phases. The prominent break conditions are defined in the year 2002 and the prominent active monsoon condition are defined in the years. The subsequent section consists of discussion on break monsoon condition in the year 2002 and active monsoon condition in the year 1994. The outgoing long wave radiation (OLR) and precipitation distribution during active spell 1994 is shown in figure $4(\mathrm{a}-\mathrm{b})$, respectively. The OLR is least $\left(180 \mathrm{Wm}^{-2}\right)$ over head Bay of Bengal region (figure 4a) and it increases as we move northwestward (from 190 to $300 \mathrm{Wm}^{-2}$ ). Thus, the OLR distribution during active spell 1994 suggests active oceanic tropical convergence zone (ITCZ). The GPCP precipitation (figure 4b) during active spell 1994 show highest rainfall over central India (400-600 mm) and west coast $(\geq 300 \mathrm{~mm})$. However, the rainfall received over Indo-Gangetic plains and northeast India (300-400 mm) is less as compared to that over central India. The result suggests active OTCZ is cause of heavy rainfall over central India during active spell 1994. Further, the OLR and GPCP precipitation distribution is examined during break spell 2002 (figure 5a-b). The OLR values during break spell 2002 (figure 5a) are greater as compared to OLR values during 
Active Spell

(a)

Phase1 (1979-2013)

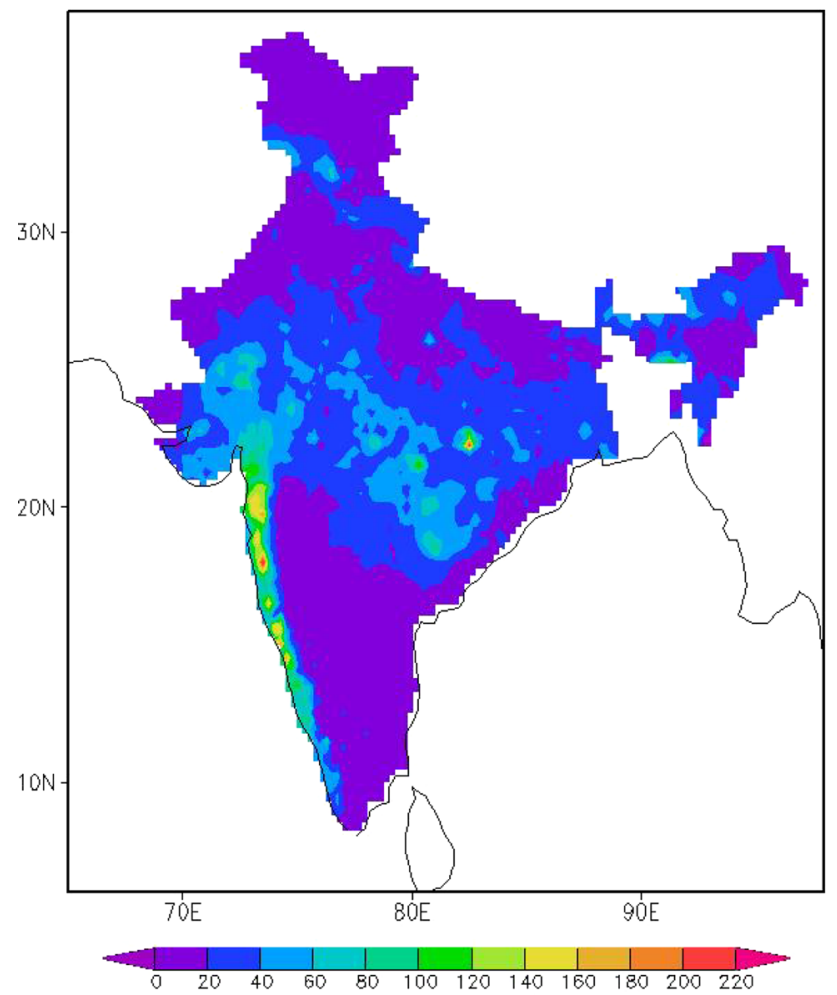

(c)

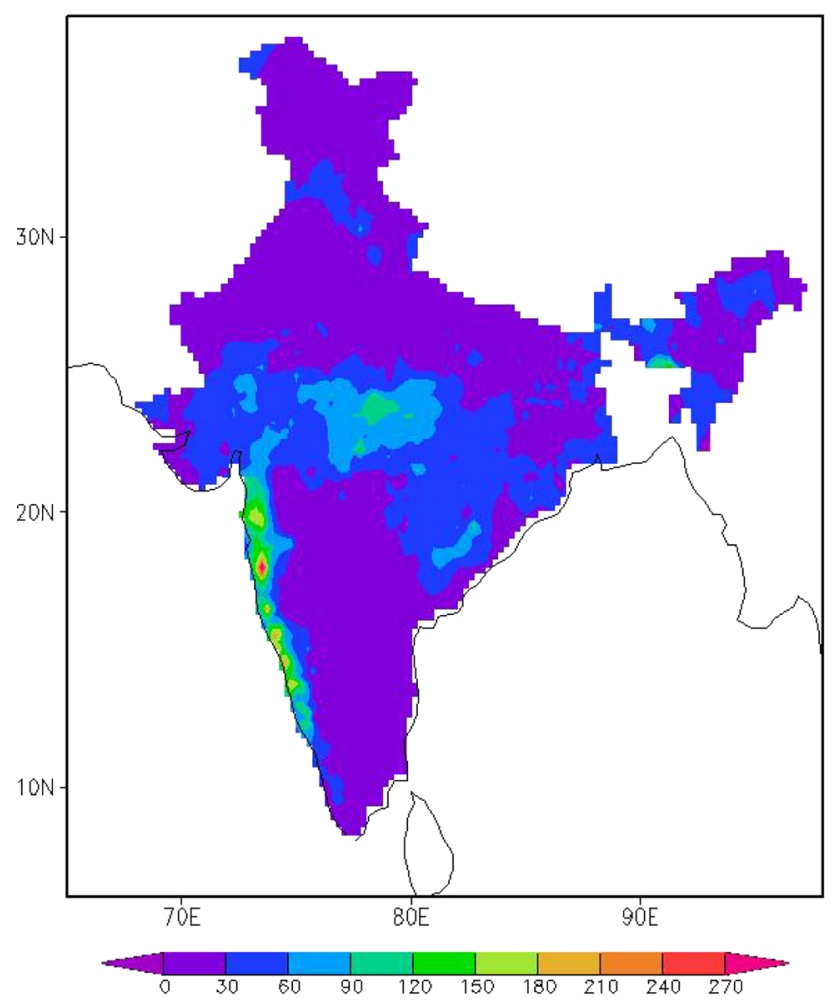

\section{Break Spell}

(b) Phase 1(1979-2013)

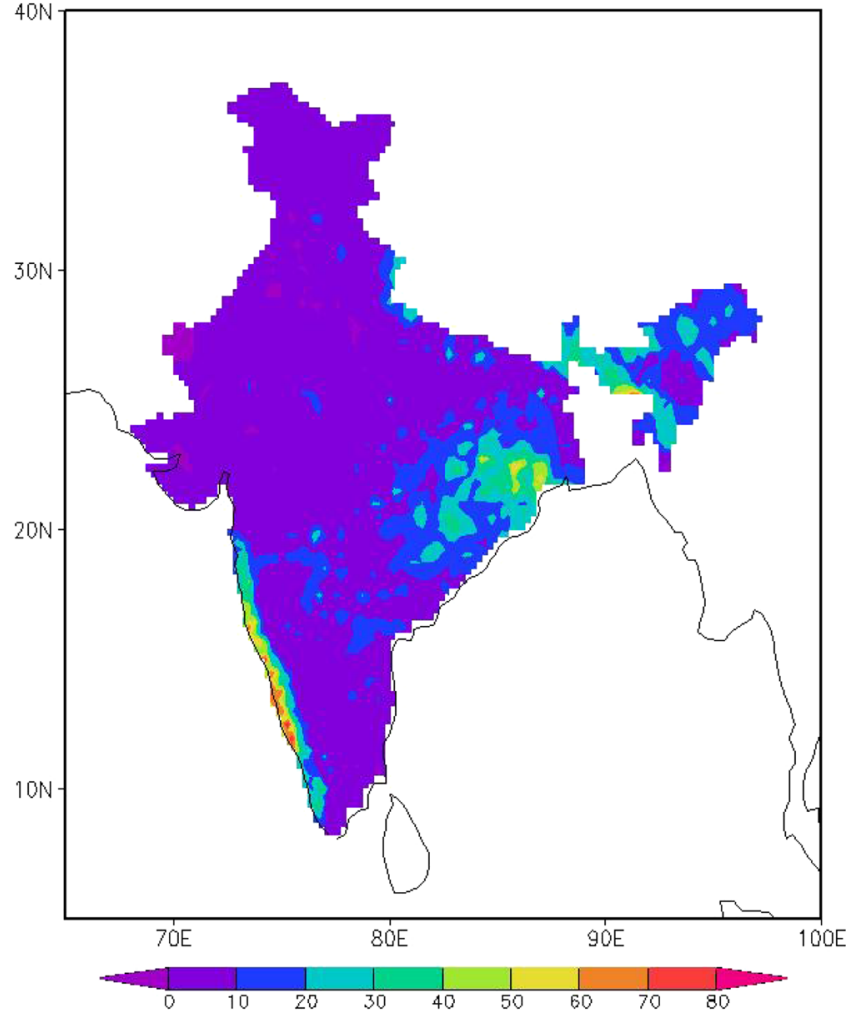

(d)

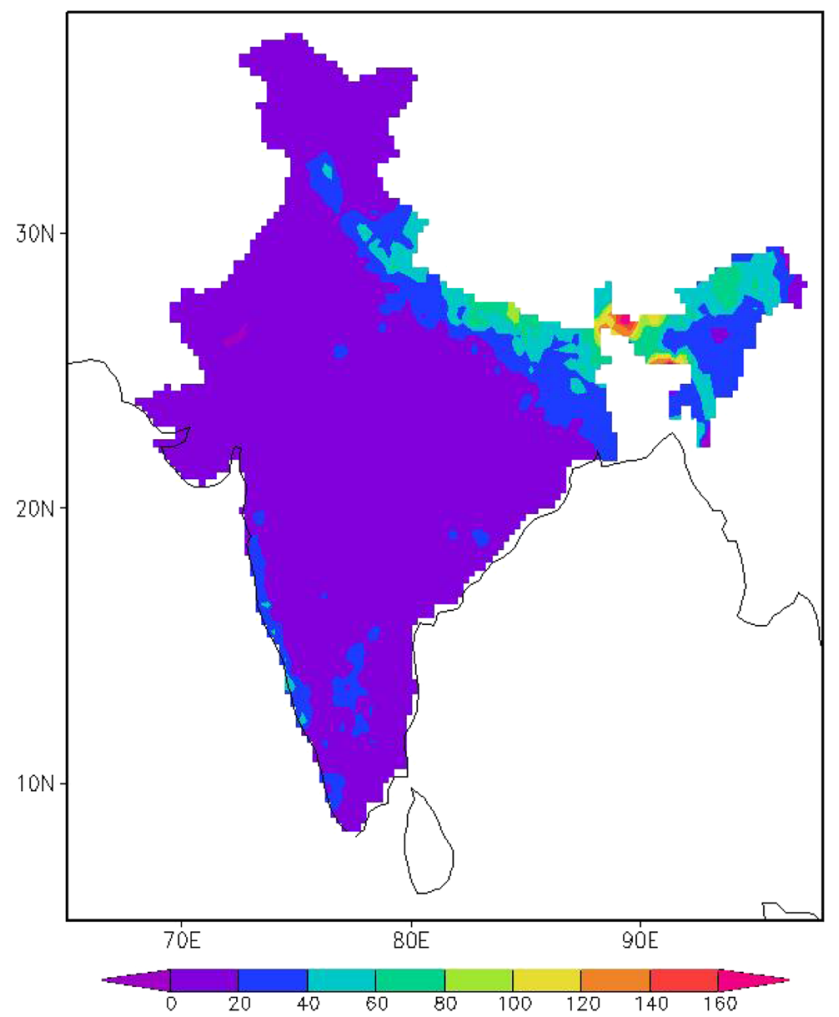

Figure 3. The rainfall distribution corresponding to MJO phases 1-8 (a-h) during active spell (left panel) and break spell (right panel) for the period 1979-2013. 
(e)

Phase3 (1979-2013)

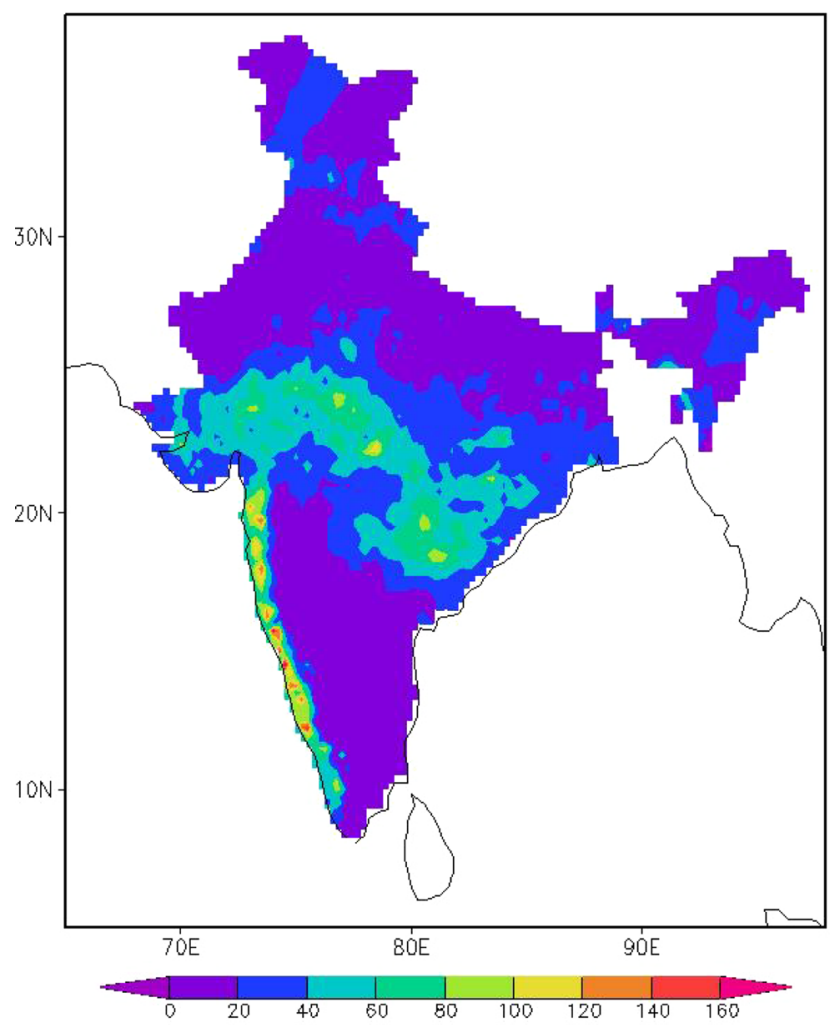

(g)

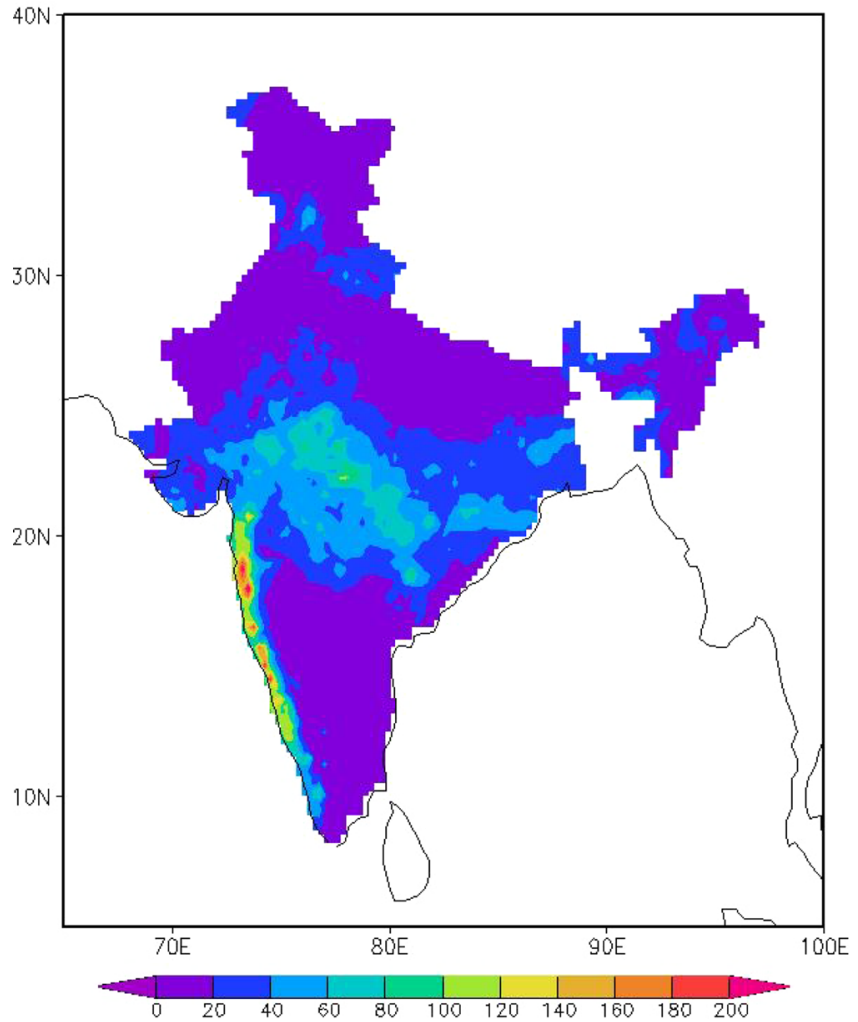

(f)

Phose 3 (1979-2013)

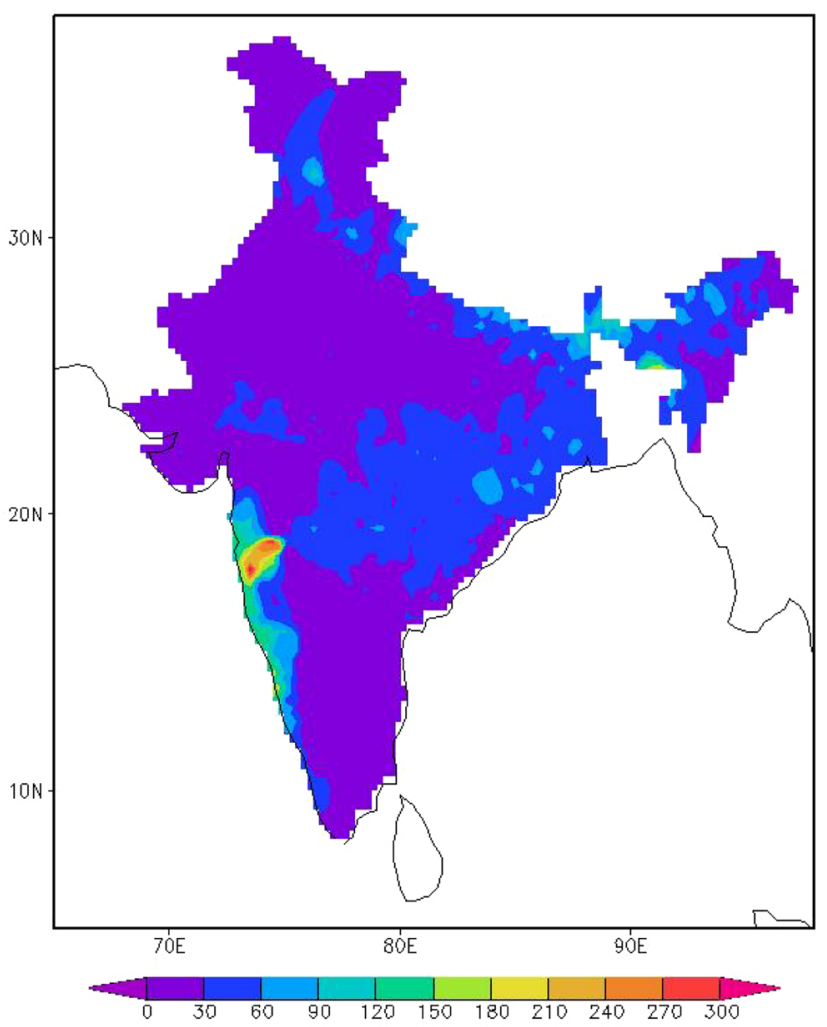

(h)

Phose 4 (1979-2013)

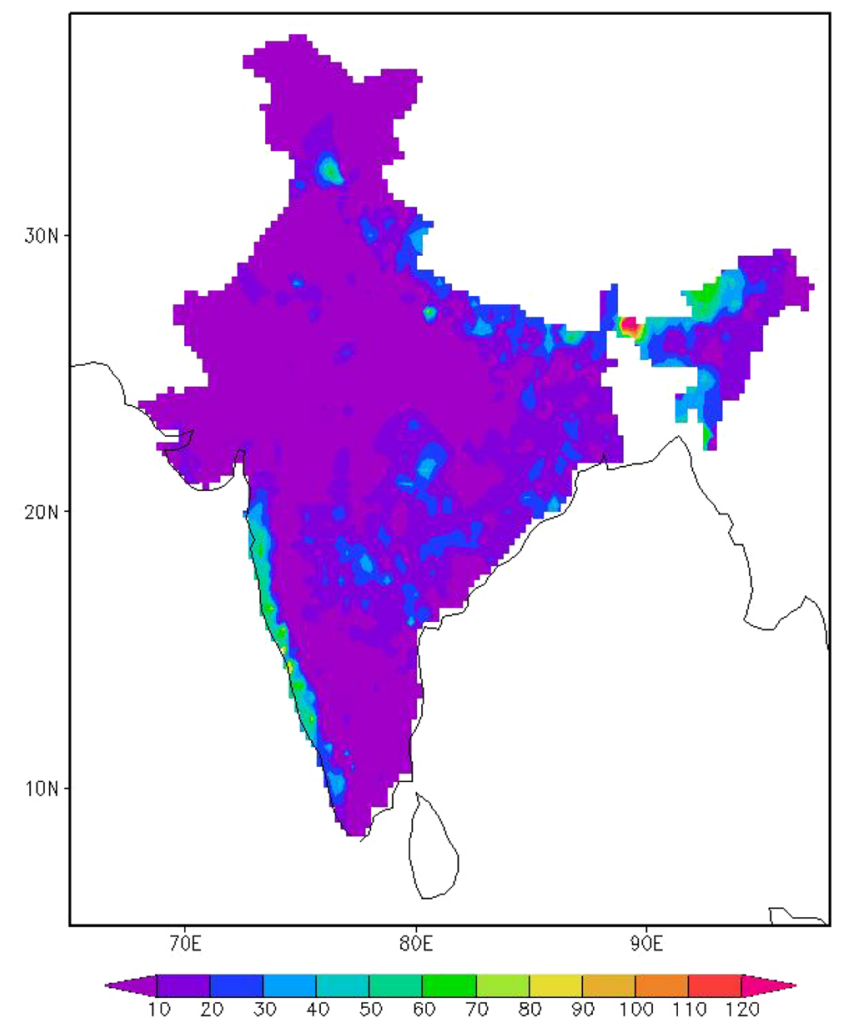

Figure 3 (Continued.) 
(i)

Phase5 (1979-2013)

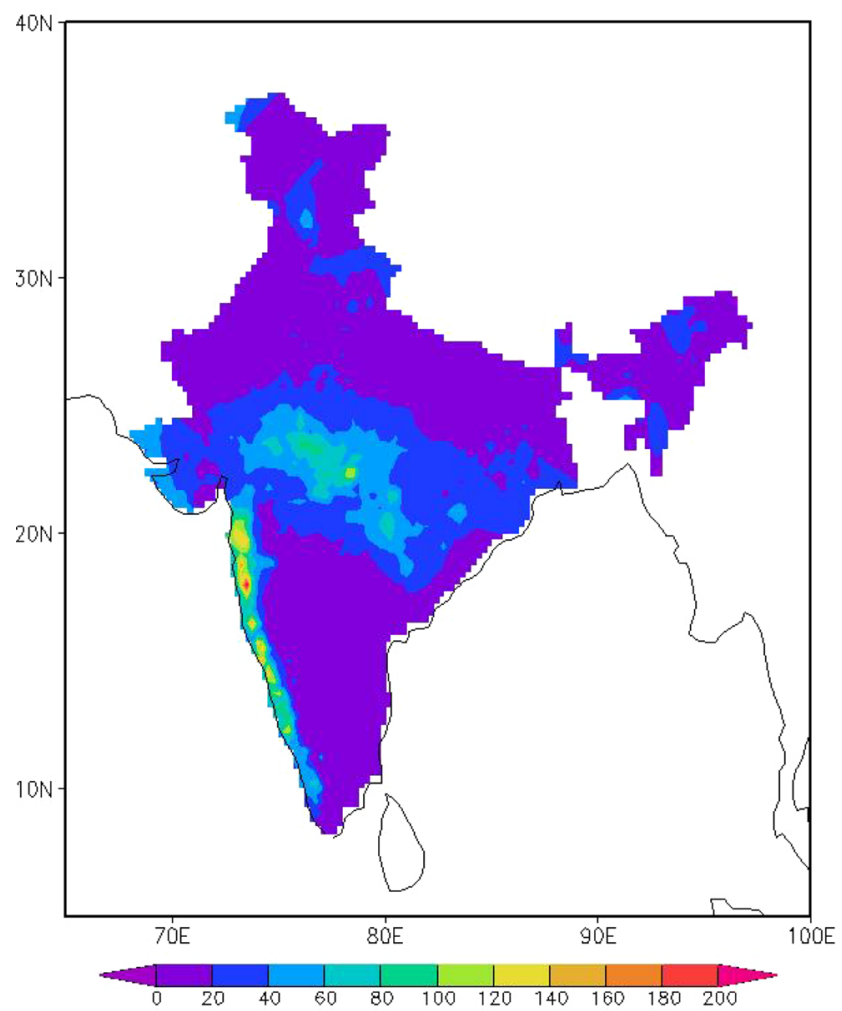

(k)

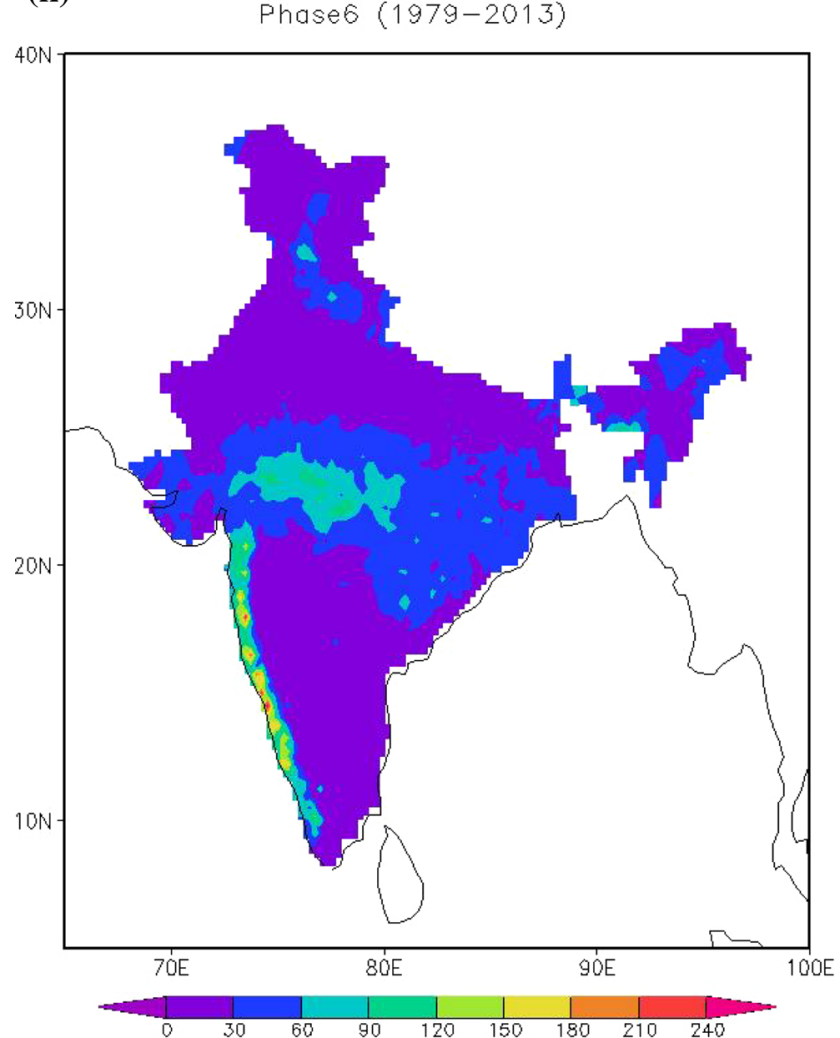

(j)

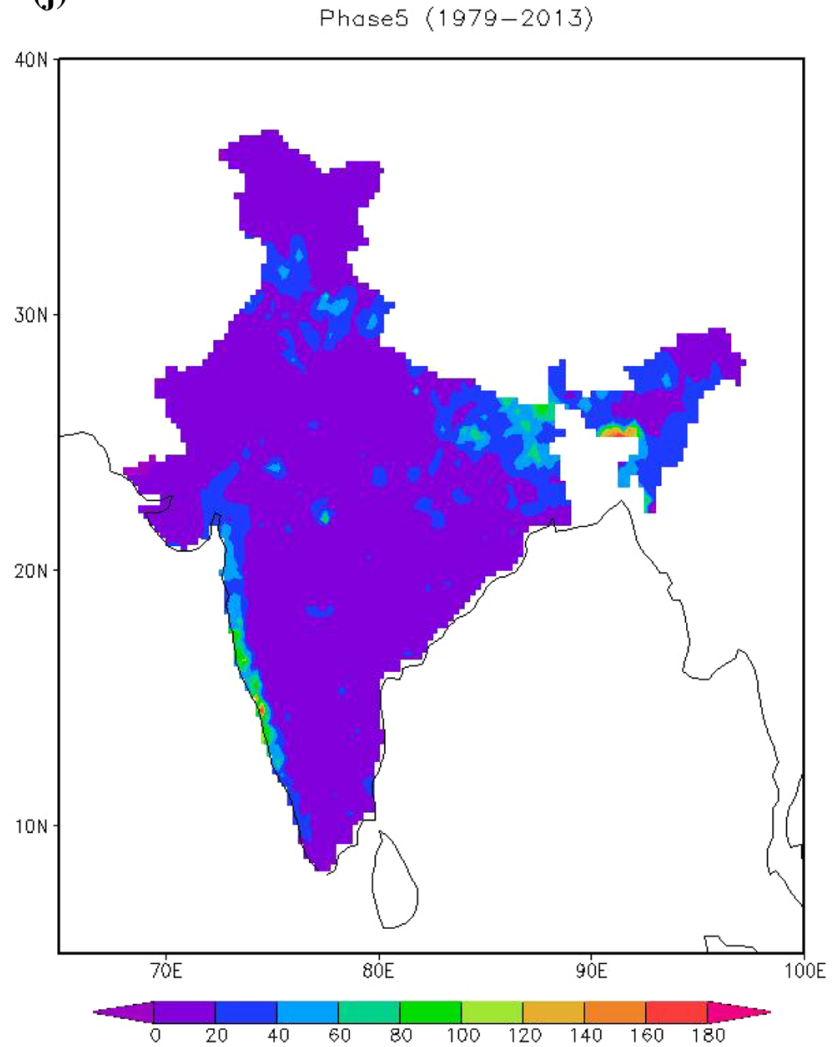

(I)

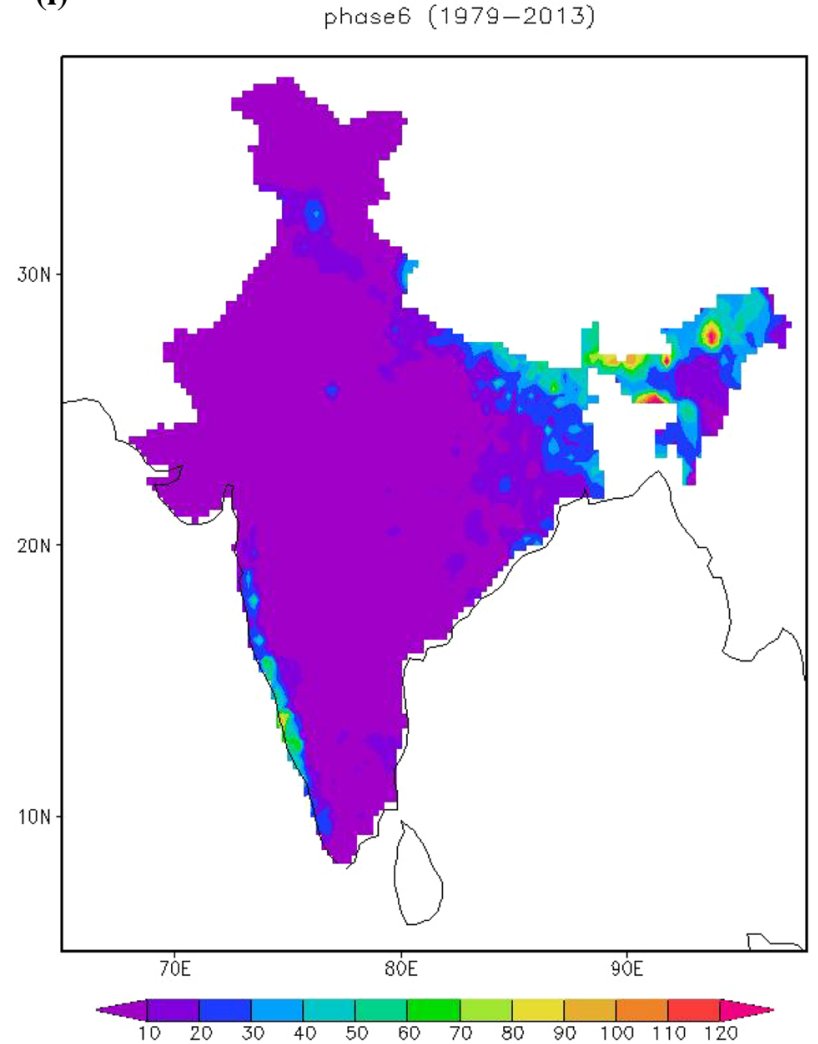

Figure 3 (Continued.) 
(m)

Phase7 (1979-2013)

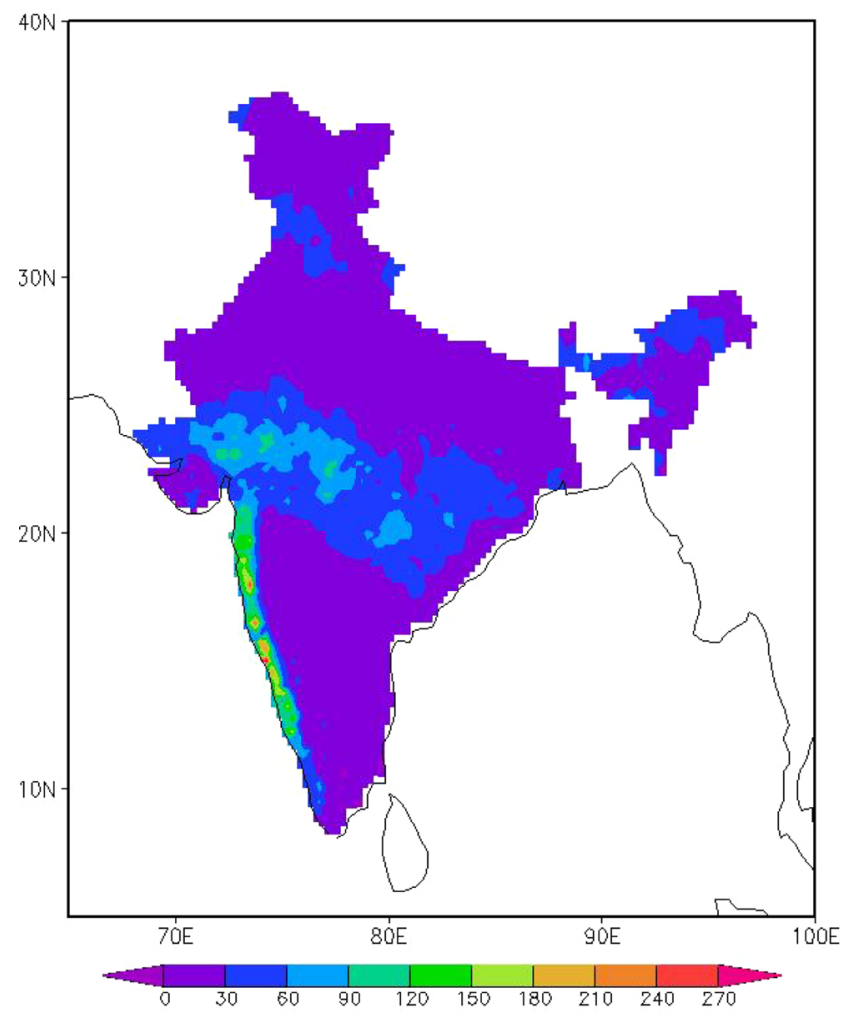

(o)

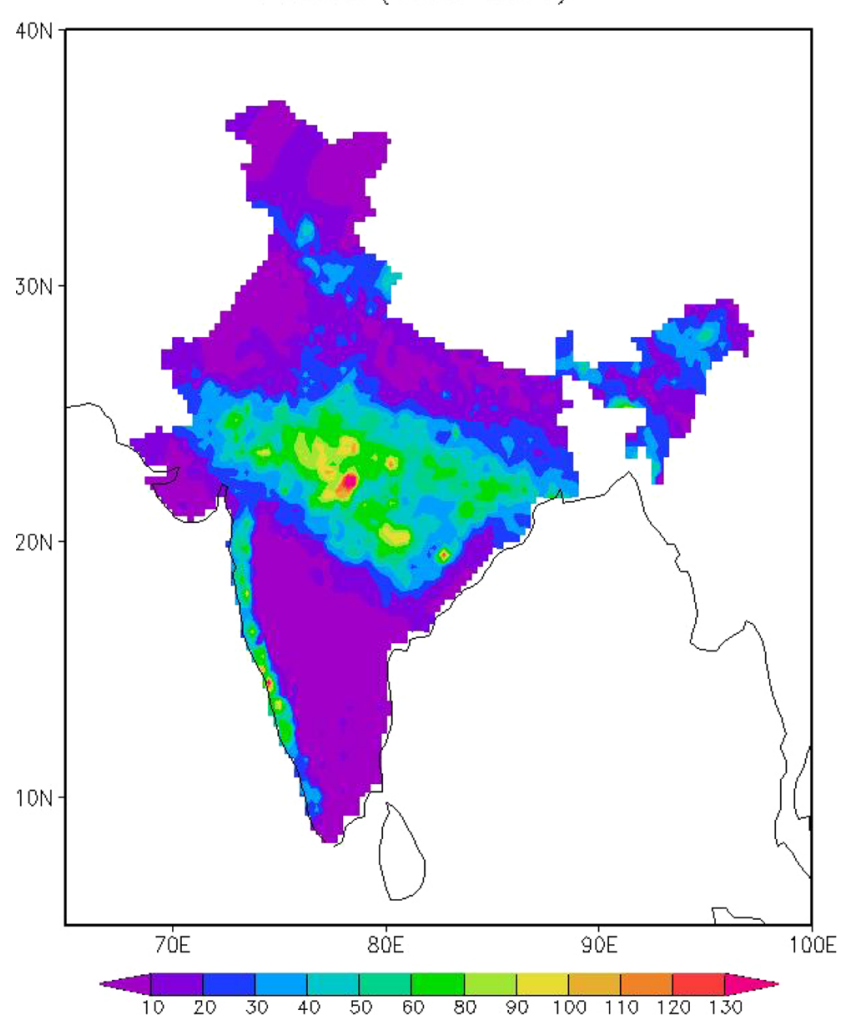

(n) Phase7 (1979-2013)

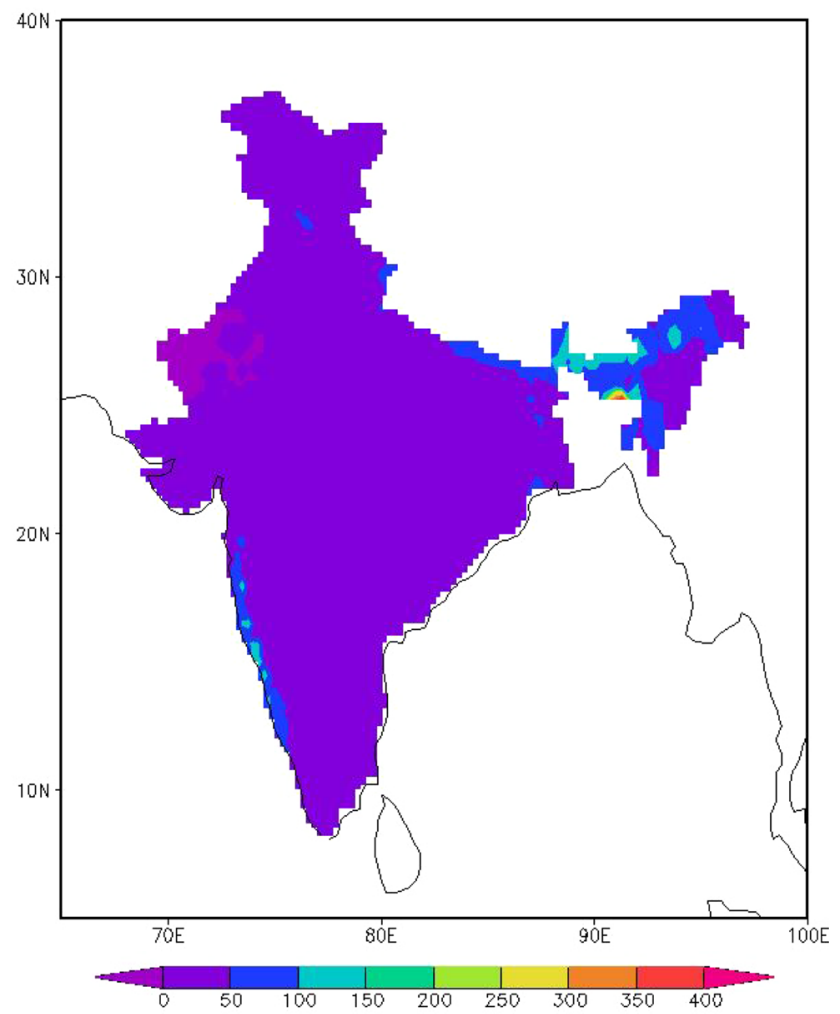

(p) Phase8 (1979-2013)

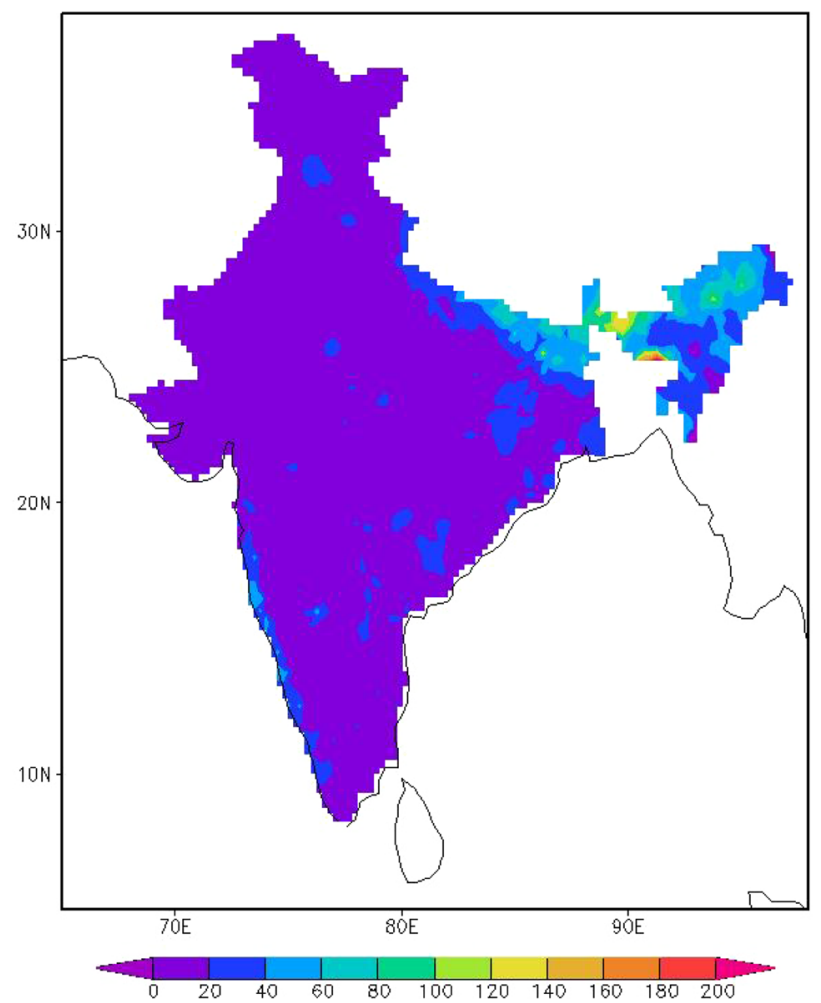

Figure 3 (Continued.) 
(a)

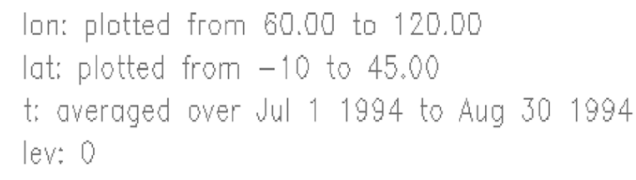

Mean olr $\mathrm{W} m-2$

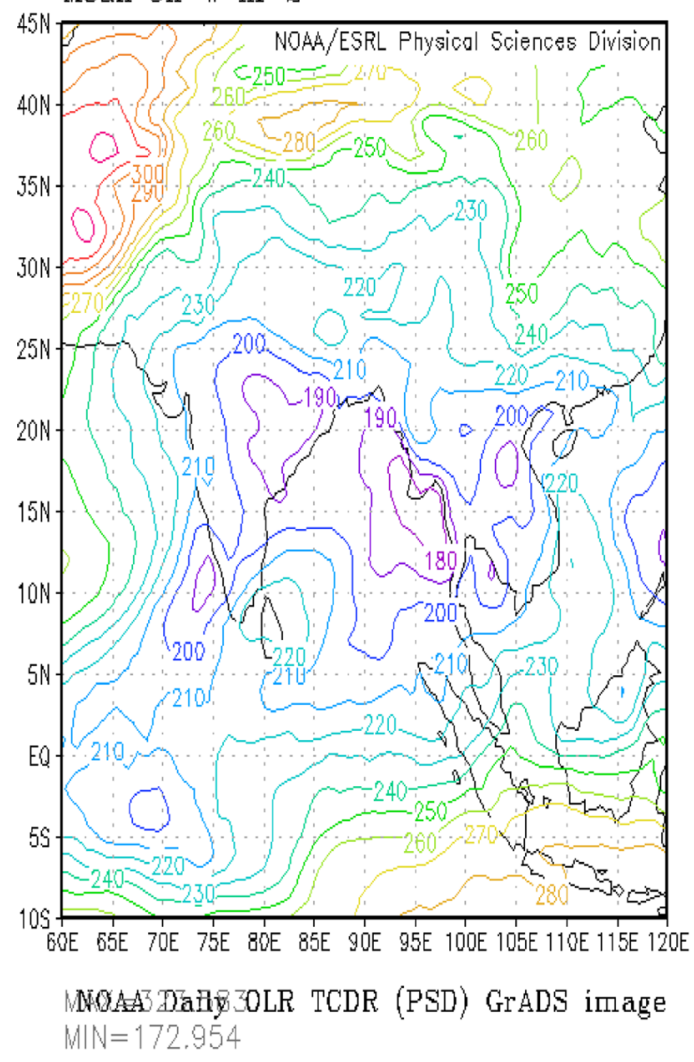

(b)

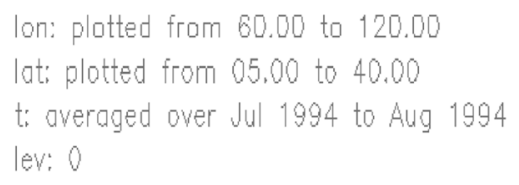

Ion: plotted from 60.00 to 120.00

lat: plotted from 05.00 to 40.00

t: averaged over Jul 1994 to Aug 1994

lev: 0

Total precip mm

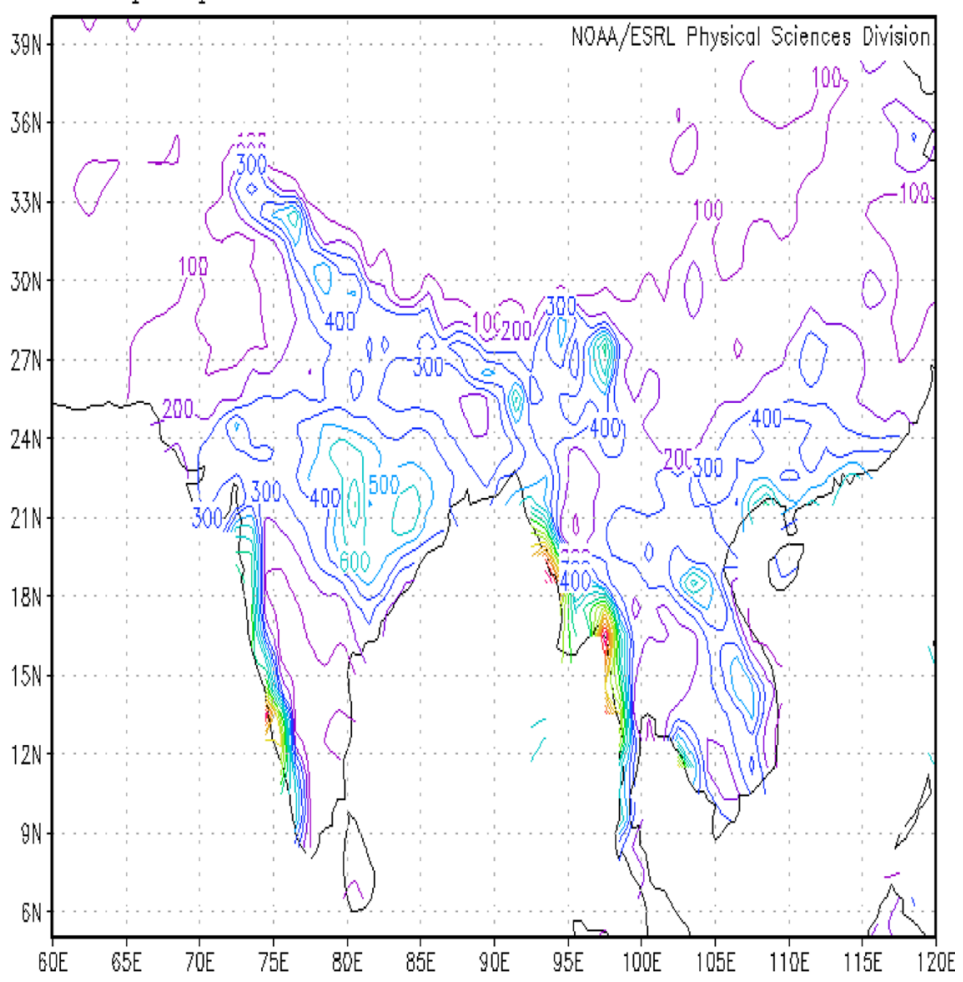

MAX $=1829.27$ GPCC Precipitation Full V8 (1.0x1.0) GrADS image $M \| N=0$

Figure 4. The active monsoon features in the year 1994. (a) OLR $\left(\mathrm{Wm}^{-2}\right)$ and (b) total precipitation (mm).

active spell 1994. The OLR values over head Bay of Bengal lies in the range 190 to $200 \mathrm{Wm}^{-2}$. There occur increase in OLR values as we move northwestwards (from 210 to $320 \mathrm{Wm}^{-2}$ ). It shows active intertropical convergence zone (OTCZ) during break spell 2002. The active OTCZ during break spell 2002 is responsible for incidences of heavy precipitation (figure 5b) over Indo-Gangetic plains and northeast India (400 to $600 \mathrm{~mm}$ ). The precipitation received over central India (200-300 $\mathrm{mm}$ ) during break spell 2002 is less as compared to the precipitation received during active spell 1994. The results of this study are consistent with the findings of Pai et al. (2011) that the break spell of ISM occur during MJO phases 1-2 and active-spell occur during MJO phases 5-6. Pai et al. (2011) have shown that during MJO phases 1-3 the break monsoon condition prevail due to active OTCZ and the active monsoon conditions during MJO phases 4-6 prevail due to active ITCZ. Wang et al. (2005) find active spell of ISM during MJO phases 7-8 and break spell of ISM during MJO phases 1-3. They have suggested a self induction mechanism responsible for maintenance of intraseasonal oscillation (ISO). Annamalai and Slingo (2001) have shown that the enhanced convection over Africa coincides with enhanced convection over equatorial Indian Ocean. Another important finding of this study is observed that the strong impact of MJO on the onset of break and active monsoon events over India and their duration. Though, the amplitude of the MJO plays a significant role in this association, the phase of the MJO seems to be more deciding factor. 
(a)
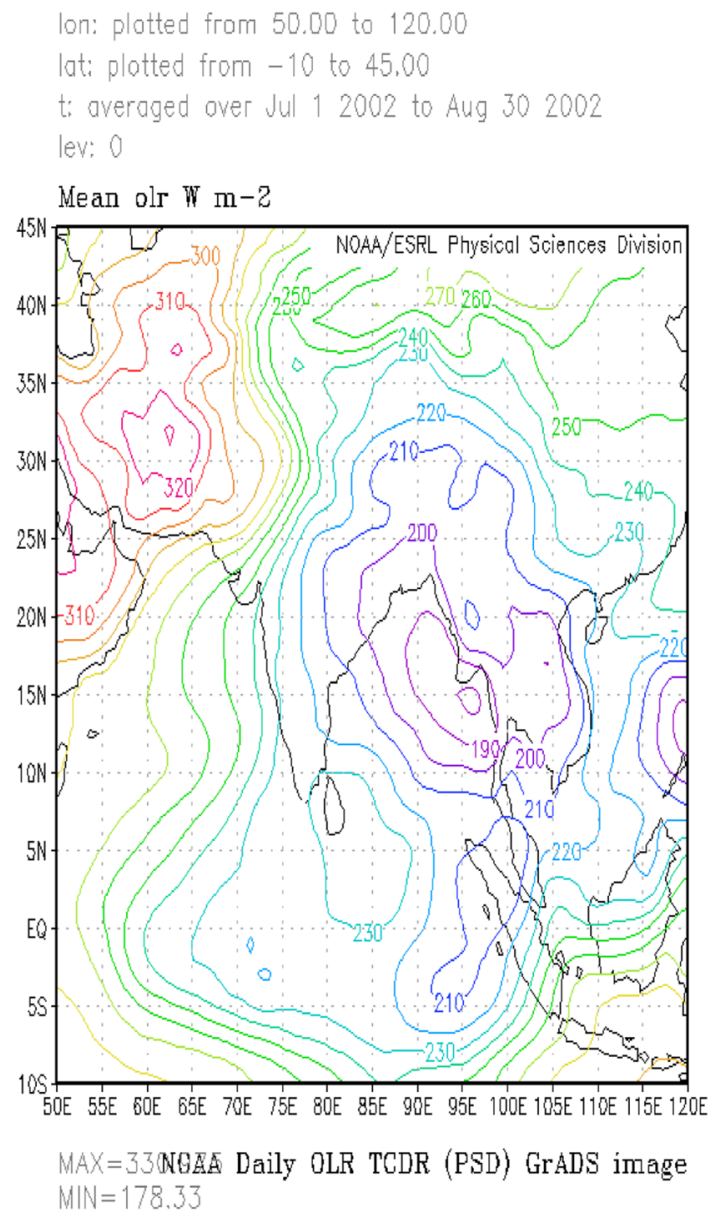

(b)

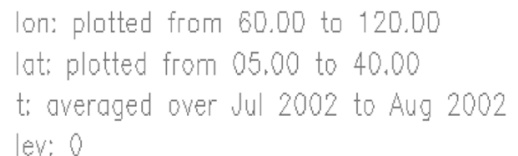

Total precip mm

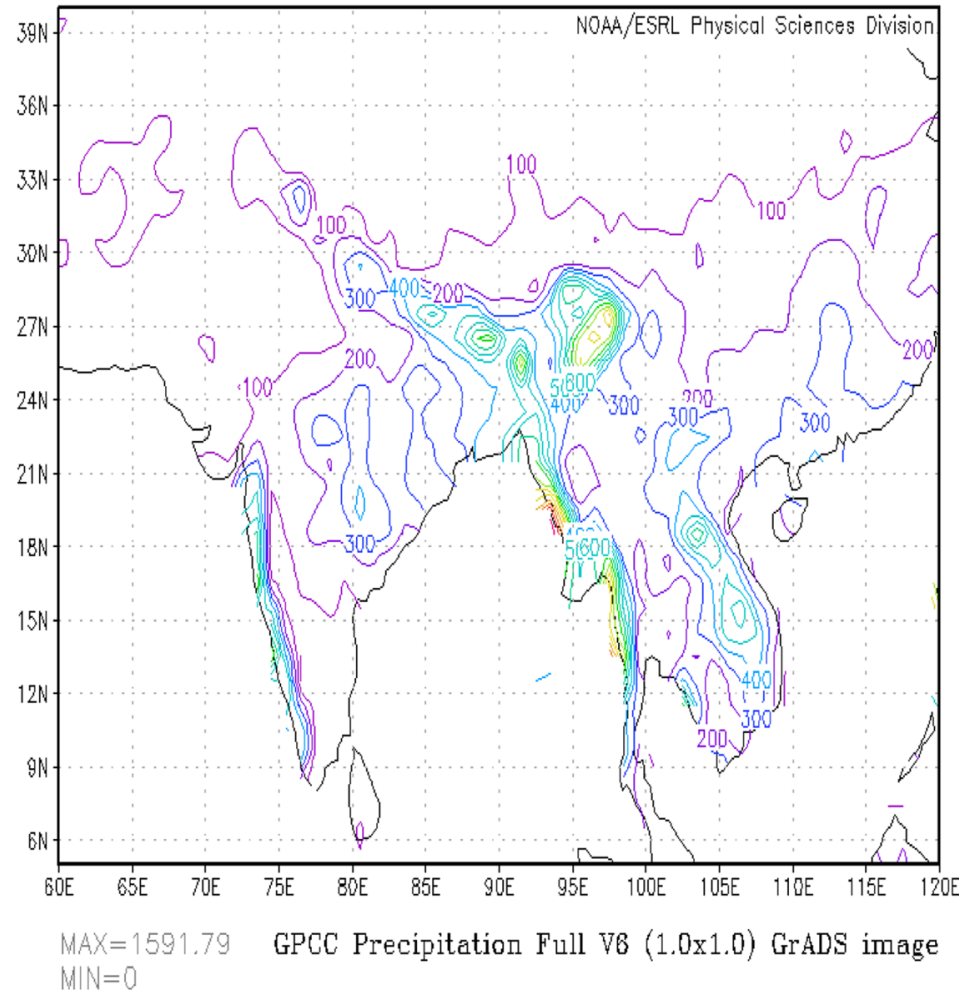

Figure 5. The break monsoon features in the year 2002. (a) OLR $\left(\mathrm{Wm}^{-2}\right)$ and (b) total precipitation (mm).

\section{Conclusions}

The composite rainfall anomaly analysis associated with the various phases of MJO revealed strong intraseasonal variation in the spatial rainfall anomaly distribution over India. The break monsoon rainfall distribution is observed during phases 1 and 2, and the active monsoon rainfall distribution is observed during phases 5 and 6 . The MJO phase 8 is associated with heavy rainfall conditions over central India. The prominent break monsoon conditions in the year 2002 are associated with active ITCZ and the prominent active monsoon conditions in the year 1994 are associated with active OTCZ. Further, the results suggest that the active events occur during MJO phases 5 (16\% of days) and 6 (21\% of days), while break events occur during MJO phases 1 (34\% of days) and 2 (18\% of days). Thus, it may be concluded that active break cycle mostly occur during MJO phases 1 ( $86 \%$ of years), 2 (70\% of years), 7 (62\% of years) and
8 (56\% of years). Subsequently, as the MJO propagated eastwards, a gradual northward shift of the above normal rainfall band from south peninsula to north India was observed. Several studies have reported northward propagation of cloud bands over Indian monsoon region with MJO periodicity (Yasunari 1979; Sikka and Gadgil 1980; Gadgil 2003; Singh et al. 2016). During phases 5 and 6 , the above normal rainfall band was observed along monsoon trough region and active monsoon type rainfall distribution was observed. During the subsequent phases 7 and 8 , a general decrease in the rainfall was observed over most parts of the country. Short rain-breaks occur during MJO phases 1 and 4, while long rain-breaks occur during MJO phase 8. The large scale Hadley and east-west circulation covering most of the tropics are significantly modulated during active phases. It is proposed that the Rossby wave emanating from the west Pacific appears to be responsible for the northward propagation of convection. 
This study has shown that there occur eastward propagating MJO phases on most of the occasion. There are few occasion during which there occur westward propagating phases. The eastward propagating phases are manifestation of equatorially trapped Kelvin wave and it enhances the climatic event. The westward propagating phases on few occasions are associated with Rossby wave emanation and it always delays or suppresses the climatic event. The findings of the present study may be useful for extended range prediction of active-break spell of summer monsoon and for attaining better MJO forecast skill.

\section{Acknowledgements}

The authors are very much grateful to Dr D R Pattanaik, India Meteorological Department, New Delhi for his valuable suggestions that helped a lot in improving the quality of this paper. The Bureau of Meteorology (http://www.bom.gov.au/climate/ mjo/) is thankfully acknowledged for providing real-time MJO data. The GPCP precipitation and OLR data is provided at http://www.esrl.noaa. gov/psd/, which is thankfully acknowledged.

\section{References}

Abhilash S, Sahai A K, Pattnaik S, Goswami B N and Kumar A 2014 Extended range prediction of active-break spells of Indian summer monsoon rainfall using an ensemble prediction system in NCEP climate forecast system; Int. J. Climatol. 34(1) 98-113.

Annamalai H and Slingo J M 2001 Active/break cycles: Diagnosis of the intraseasonal variability of the Asian summer monsoon; Clim. Dyn. 18 85-102.

Bhatla R, Singh M and Pattanaik D R 2016 Impact of Madden-Julian oscillation on onset of summer monsoon over India; Theor. Appl. Climatol., https://doi.org/10. 1007/s00704-015-1715-4.

Bhatla R, Singh M, Mall R K, Tripathi A and Raju P V S 2015 Variability of summer monsoon rainfall over IndoGangetic plains in relation to El-Nino/La-Nina; Nat. Hazards 78(2) 837-853.

Bhatla R, Mohanty U C, Raju P V S and Madan O P 2004 A study on dynamic and thermodynamic aspects of breaks in the summer monsoon over India; Int. J. Climatol. 24(3) 341-360.

Barlow M, Wheeler M, Lyon B and Cullen H 2005 Modulation of daily precipitation over southwest Asia by the Madden-Julian Oscillation; Mon. Wea. Rev. 133 35793594 .

Chen T C, Tzeng R Y and Yen M C 1988 Development and life cycle of the Indian monsoon: Effect of the 30-50 days oscillation; Mon. Wea. Rev. 116 2183-2199.
Ding Y H and Sikka D R 2006 Synoptic systems and weather; In: The Asian Monsoon (ed.) Wang B, Praxis Publishing Ltd., Chichester, UK, pp. 131-202.

Gadgil S and Asha G 1992 Intraseasonal variation of the summer monsoon. I: Observational aspects; J. Meteor. Soc. Japan 70 517-527.

Gadgil S 2003 The Indian monsoon and its variability; Ann. Rev. Earth Planet. Sci. 31(1) 429-467.

Gadgil S and Joseph P V 2003 On breaks of the Indian monsoon; Proc. Indian Acad. Sci. 112 529-558.

Joseph S, Sahai A K and Goswami B N 2009 Eastward propagating MJO during boreal summer and Indian monsoon droughts; Clim. Dyn. 32(7-8) 1139-1153.

Klingaman N P, Jiang X, Xavier P K, Waliser D and Woolnough S J 2015 Vertical structure and physical processes of Madden-Julian Oscillation: Synthesis and summary; $J$. Geophys. Res. Atmos. 120 4671-4689, https://doi.org/10. 1002/2015JD023196.

Kulkarni A, Kripalani R, Sabade S and Rajeevan M 2011 Role of intra-seasonal oscillations in modulating Indian summer monsoon rainfall; Clim. Dyn. 36(5-6) 10051021.

Krishnamurthy T N and Ardanuy P 1980 The 10 to 20 day westward propagating mode and breaks in the monsoon; Tellus 32 15-26.

Krishnamurthy V and Shukla J 2008 Seasonal persistence and propagation of intraseasonal patterns over the Indian summer monsoon region; Clim. Dyn. 30 353-369.

Krishnamurti T N, Jayakumar P K, Sheng J, Surgi N and Kumar A 1985 Divergent circulations on the 30 to 50 day time scale; J. Atmos. Sci. 42 364-375.

Lau K M and Chan P H 1986 Aspects of the 40-50 day oscillation during the northern summer as inferred from outgoing longwave radiation; Mon. Wea. Rev. 1141354 1367.

Madden R A and Julian P R 1972 Description of global-scale circulation cells in the tropics with a 40-50 day period; J. Atmos. Sci. 29(6) 1109-1123.

Pai D S, Bhate J, Sreejith O P and Hatwar H R 2011 Impact of MJO on the intraseasonal variation of the summer monsoon rainfall over India; Clim. Dyn. 36(1-2) 41-55, https://doi.org/10.1007/s00382-009-0634-4.

Pai D S, Sridhar L and Kumar M R 2016 Active and break events of Indian summer monsoon during 19012014; Clim. Dyn. 46(11-12) 3921-3939.

Rajeevan M, Gadgil S and Bhate J 2010 Active and break spells of the Indian summer monsoon; J. Earth Syst. Sci. 119(3) 229-247.

Rui H and Wang B 1990 Development characteristics and dynamic structure of tropical intraseasonal convection anomalies; J. Atmos. Sci. 47 357-379.

Singh M, Bhatla R and Pattanaik D R 2016 An apparent relationship between Madden-Julian Oscillation and the advance of Indian summer monsoon; Int. J. Climatol. 37(4) 1951-1960.

Sikka D R and Gadgil S 1980 On the maximum cloud zone and the ITCZ over India longitude during the southwest monsoon; Mon. Wea. Rev. 108 1840-1853.

Wang B, Webster P J and Teng H 2005 Antecedents and selfinduction of active-break south Asian monsoon unraveled by satellites; Geophys. Res. Lett. 32(4), https://doi.org/ 10.1029/2004GL020996. 
Wheeler M C and Hendon H H 2004 An all-season real-time multivariate MJO Index: Development of an index for monitoring and prediction; Mon. Wea. Rev. 132 19171932.

Valadao C E A, Carvalho L M V, Lucio P S and Chaves R R 2016 Impact of the Madden-Julian Oscillation on intraseasonal precipitation over Northeast Brazil; Int. J. Climatol. 37(4) 1859-1884.

Yasunari T 1979 Cloudiness fluctuations associated with the northern Hemisphere summer monsoon; J. Meteor. Soc. Japan 57 227-242.

Yasunari T 1980 A quasi-stationary appearance of 30 to 40 day period in the cloudiness fluctuations during the summer monsoon over India; J. Meteor. Soc. Japan 58 $225-229$.

Corresponding editor: AsHoK KARUmuRI
Yasunari T 1981 Structure of an Indian summer monsoon system with around 40-day period; J. Meteor. Soc. Japan 59 336-354.

Zheng Y, Bourassa M A, Ali M M and Krishnamurti T N 2016 Distinctive features of rainfall over the Indian homogeneous rainfall regions between strong and weak Indian summer monsoons; J. Geophys. Res. Atmos. 121(10) 5631-5647.

Zheng Y, Ali M M and Bourassa M A 2016 Contribution of monthly and regional rainfall to the strength of Indian summer monsoon; Mon. Wea. Rev., https://doi.org/10. 1175/MWR-D-15-0318.1.

Zhang C 2005 Madden-Julian Oscillation; Rev. Geophys. 43 $1-36$. 